\title{
TEKNIK ANALISIS AMONIA DI DANAU KENALI JAMBI METODE PHENATE
}

\author{
Agus Sudrajat ${ }^{1)}$ \\ 1) Teknisi Litkayasa pada Balai Riset Perikanan Perairan Umum, Mariana-Palembang \\ Teregristasi I tanggal: 19 Mei 2005; Diterima setelah perbaikan tanggal: 14 September 2007; \\ Disetujui terbit tanggal: 11 Mei 2007
}

\section{PENDAHULUAN}

Suatu perairan yang mengalami pencemaran, maka kadar amonia tinggi. Nilai amonia harus di bawah 0,5 mg per I, sedangkan untuk keperluan air minum kadar amonia harus nol (Alaerts \& Santika, 1984). Suatu perairan dengan kandungan amonia yang tinggi akan mengganggu pertumbuhan dan kehidupan ikan serta organisme lain.

Sumber utama yang menyebabkan tinggi kadar amonia air kolam, dapat disebabkan oleh ekskrasi organisme perairan yang bersifat hewani, juga dari sisa-sisa pakan yang tidak termanfaatkan oleh organisme. Jumlah amonia yang dikeluarkan dapat diduga dari pemanfaatan protein bersih (bobot protein yang dihasilkan ikan dikurang bobot protein dalam makanan) dan persentase protein dalam makanan (Tucker \& Boyd, 1985). Pada pH rendah amonia merupakan senyawa nitrogen yang dapat berubah menjadi $\mathrm{NH} 4+$.

Dalam suatu perairan kualitas air merupkan faktor yang penting untuk diketahui baik faktor kimia maupun fisika, antara lain amonia dalam perairan. Amonia dalam perairan merupakan indikator pembusukkan dari sisa-sisa bahan organik yang merukapan yang terlarut dalam perairan.

\section{PENGUKURAN AMONIA DENGAN SPEKTROPOTOMETRI}

Pengukuran amonia dengan spektropotometri menggunakan metode phenate (Apha, 1985) dan alat spektropotometer spektronik 20 buatan Bausch dan Lomb.

\section{Cara Kalibrasi Spektropotometer Spektronic 20}

Untuk menjaga kestabilan alat, maka alat perlu di kaliberasi dengan menghidupkan (on) alat sampai dengan jarum bergerak ke angka nol absorban, lalu biarkan selama 30 menit sampai dengan jarum kembali ke posisi semula.

\section{Cara Analisis Amonia Spektropotometri dengan Metode Phenate}

1. Setelah di kaliberasi, tepatkan panjang gelombang (ë $630 \mathrm{~nm}$ ).

2. Lalu larutan blanko $(10 \mathrm{ml}$ aquades $+0,05 \mathrm{ml}$ larutan $\mathrm{MnSO} 40,03 \mathrm{~m}+0,5 \mathrm{ml}$ larutan $\mathrm{NaO} \mathrm{Ol}$ $5 \%+0,6 \mathrm{ml}$ larutan phenate) masukan ke test tube (cuvet) batas tanda dan ukur ke spektropotometer agar alat konstan dengan mengatur sampai dengan jarum menunjukkan di angka nol absorban.

3. Lalu larutan standar amonia yang terdiri atas 0,5 ml larutan stock $\mathrm{NH} 40,1 \mathrm{~N}+9,5 \mathrm{ml}$ aquades:

a. 1 ml larutan stok NH4 0,1 N+9 ml aquades

b. $2 \mathrm{ml}$ larutan stok $\mathrm{NH} 40,1 \mathrm{~N}+8 \mathrm{ml}$ aquades

c. $3 \mathrm{ml}$ larutan stok NH4 $0,1 \mathrm{~N}+7 \mathrm{ml}$ aquades

d. $4 \mathrm{ml}$ larutan stok NH4 $0,1 \mathrm{~N}+6 \mathrm{ml}$ aquades

e. $5 \mathrm{ml}$ larutan stok $\mathrm{NH} 40,1 \mathrm{~N}+5 \mathrm{ml}$ aquades

f. $6 \mathrm{ml}$ larutan stok $\mathrm{NH} 40,1 \mathrm{~N}+4 \mathrm{ml}$ aquades

g. $7 \mathrm{ml}$ larutan stok $\mathrm{NH} 40,1 \mathrm{~N}+3 \mathrm{ml}$ aquades

h. $8 \mathrm{ml}$ larutan stok $\mathrm{NH} 40,1 \mathrm{~N}+2 \mathrm{ml}$ aquades

i. $9 \mathrm{ml}$ larutan stok $\mathrm{NH} 40,1 \mathrm{~N}+1 \mathrm{ml}$ aquades

Kemudian dari masing-masing larutan di atas (a sampai dengan j) tambahkan secara berurutan dengan 0,05 ml larutan MnSO4 0,03 M+0,5 larutan $\mathrm{Na} \mathrm{Cl} \mathrm{5 \% +0,6} \mathrm{ml} \mathrm{larutan} \mathrm{phenate.} \mathrm{Lalu} \mathrm{diukur}$ untuk mendapatkan masing-masing angka absorban secara berurutan dengan menggunakan test tube (cuvet).

4. Kemudian air contoh ( $10 \mathrm{ml}$ air contoh $+0,05 \mathrm{ml}$ larutan $\mathrm{MnSO} 4$ 0,03 $\mathrm{M}+0,5 \mathrm{ml}$ larutan $\mathrm{NaO} \mathrm{Ol}$ $5 \%+0,6 \mathrm{ml}$ larutan phenate) masukan ke test tube (cuvet) batas tanda dan ukur ke alat spektropotometer untuk mendapatkan angka absorban. 
Tabel 1. Ditentukan dalam $1 \mathrm{ml}$ larutan standar ammonia mengandung $0,5 \mu \mathrm{N}-\mathrm{NH}_{3}$

\begin{tabular}{ccc}
\hline No. & Larutan standar ammonia $\mathbf{( m l )}$ & Konsentrasi $\mathbf{( x )}$ \\
\hline 1. & $0,5 \times 0,5$ & 0,25 \\
2. & $1 \times 0,5$ & 0,5 \\
3. & $2 \times 0,5$ & 1 \\
4. & $3 \times 0,5$ & 1,5 \\
5. & $4 \times 0,5$ & 2 \\
6. & $5 \times 0,5$ & 2,5 \\
7. & $6 \times 0,5$ & 3 \\
8. & $7 \times 0,5$ & 3,5 \\
9. & $8 \times 0,5$ & 4 \\
10. & $9 \times 0,5$ & 4,5 \\
\hline
\end{tabular}

Tabel 2. Angka konsentrasi $(\mathrm{x})$ dan angka absorban $(\mathrm{Y})$

\begin{tabular}{ccc}
\hline No. & Konsentrasi $(\mathbf{x})$ & Absorban $(\mathbf{Y})$ hasil pengukuran \\
\hline 1. & 0,25 & 0,011 \\
2. & 0,5 & 0,016 \\
3. & 1 & 0,044 \\
4. & 1,5 & 0,056 \\
5. & 2 & 0,070 \\
6. & 2,5 & 0,08 \\
7. & 3 & 0,096 \\
8. & 3,5 & 0,125 \\
9. & 4 & 0,155 \\
10. & 4,5 & 0,177 \\
\hline
\end{tabular}

Tabel 3. Perhitungan persamaan regresi liner sederhana penentuan kadar amonia

\begin{tabular}{ccccccc}
\hline Absorban $(\mathbf{Y})$ & $\mathbf{Y 1 - Y}$ & $\left(\mathbf{Y 1}-\mathbf{Y}^{\prime}\right)^{\mathbf{2}}$ & $\begin{array}{c}\text { Konsentrasi } \\
(\mathbf{X})\end{array}$ & $\mathbf{X 1 - X}$ & $\left.\mathbf{( X 1 - X}^{\prime}\right)^{\mathbf{2}}$ & $\left.\mathbf{( Y 1 - Y}^{\prime}\right)\left(\mathbf{X 1}^{\prime} \mathbf{X} \mathbf{X}^{\prime}\right)$ \\
\hline 0,011 & $-0,0735$ & $5,402.10^{-3}$ & 0,25 & $-2,025$ & 4,100625 & 0,1488375 \\
0,016 & $-0,0685$ & $4,692.10^{-3}$ & 0,5 & $-1,775$ & 3,150625 & 0,1215875 \\
0,044 & $-0,0405$ & $1,640.10^{-3}$ & 1 & $-1,275$ & 1,625625 & 0,0516375 \\
0,056 & $-0,0285$ & $8,122.10^{-4}$ & 1,5 & $-0,775$ & 0,600625 & 0,0220875 \\
0,070 & $-0,0145$ & $2,102.10^{-4}$ & 2 & $-0,275$ & 0,075625 & 0,0039875 \\
0,084 & $-0,0005$ & $2.10^{-7}$ & 2,5 & 0,225 & 0,050625 & 0,0001125 \\
0,096 & 0,0115 & $1,322.10^{-4}$ & 3 & 0,725 & 0,525625 & 0,0083375 \\
0,125 & 0,0405 & $1,64.10^{-3}$ & 3,5 & 1,225 & 1,500625 & 0,0496125 \\
0,155 & 0,0705 & $4,970.10^{-3}$ & 4 & 1,725 & 2,975625 & 0,126125 \\
0,177 & 0,0925 & $8,556.10^{-3}$ & 4,5 & 2,275 & 5,175625 & 0,2104375 \\
0,0845 & & 0,0280 & 2,275 & & 19,781875 & 0,7427625 \\
\hline
\end{tabular}

Rumus:

$$
\mathrm{B}=\frac{\left(\mathrm{X} 1-\mathrm{X}^{\prime}\right)\left(\mathrm{Y} 1-\mathrm{Y}^{\prime}\right)}{\left(\mathrm{X} 1-\mathrm{X}^{\prime}\right)^{2}}
$$

$A=Y^{\prime}-B \cdot X^{\prime}$

$\mathrm{Y}=\mathrm{A}+\mathrm{B} \cdot \mathrm{X}$

di mana:

A dan $B=$ konstanta

$\mathrm{Y} \quad=$ absorban

$\mathrm{X} \quad=$ konsntrasi

$$
B=\frac{\left(X 1-X^{\prime}\right)\left(Y_{1}-Y^{\prime}\right)}{\left(X 1-X^{\prime}\right)^{2}}=\frac{0,7427625}{19,781875}=0,0376
$$

$\mathrm{A}=\mathrm{Y}^{\prime}-\mathrm{B} \cdot \mathrm{X}$

$=0,0845-0,0376(2,275)$

$=-0,00104$

$\mathrm{Y}=\mathrm{A}+\mathrm{B} \cdot \mathrm{X}$

$=-0,00104+0,0376 . X$

$$
X=\frac{Y+0,00104}{0,0376}
$$

Keterangan: satuan yang ditentukan dalam kadar $\mathrm{N}$ $\mathrm{NH}_{3}$ (ammonia) $=$ mg per $\mathrm{I}$ 


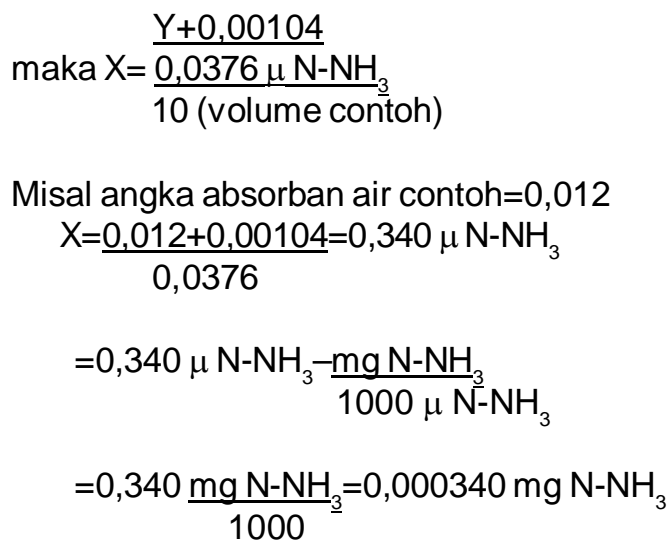

$\mathrm{X}=\frac{0,000340 \mathrm{mg} \mathrm{N}-\mathrm{NH}_{3}}{10 \mathrm{ml}}$

$=\frac{0,000340 \mathrm{mg} \mathrm{N}-\mathrm{NH}_{3}}{10 \mathrm{ml} \frac{1 \mathrm{~L}}{1000 \mathrm{ml}}}$

$=\underline{0,000340 \mathrm{mg} \mathrm{N}-\mathrm{NH}_{3}}$ $0,01 \mathrm{~L}$

Kadar $\mathrm{N}-\mathrm{NH}_{3}=0,0340 \mathrm{mg} / \mathrm{l}$

Tabel 4. Hasil analisis kadar $\mathrm{N}-\mathrm{NH}_{3}(\mathrm{mg}$ per I) Danau Kenali, Jambi, tahun 2001

\begin{tabular}{|c|c|c|}
\hline No. & Lokasi atau parameter & $\mathrm{N}-\mathrm{NH}_{3}(\mathrm{mg} / \mathrm{l})$ \\
\hline 1. & Stasiun 1 (daerah banyak gulma) & 0,053 \\
\hline 2. & Stasiun 2 (daerah banyak gulma) & 0,050 \\
\hline 3. & Stasiun 3 (daerah banyak gulma) & 0,051 \\
\hline 4. & Stasiun 4 (daerah banyak gulma) & 0,032 \\
\hline 5. & Stasiun 5 (daerah banyak gulma) & 0,034 \\
\hline 6. & Stasiun 6 (daerah banyak gulma) & 0.032 \\
\hline 7. & Stasiun 7 (daerah sedikit gulma) & 0,048 \\
\hline 8. & Stasiun 8 (daerah sedikit gulma) & 0,045 \\
\hline 9. & Stasiun 9 (daerah sedikit gulma) & 0,048 \\
\hline
\end{tabular}

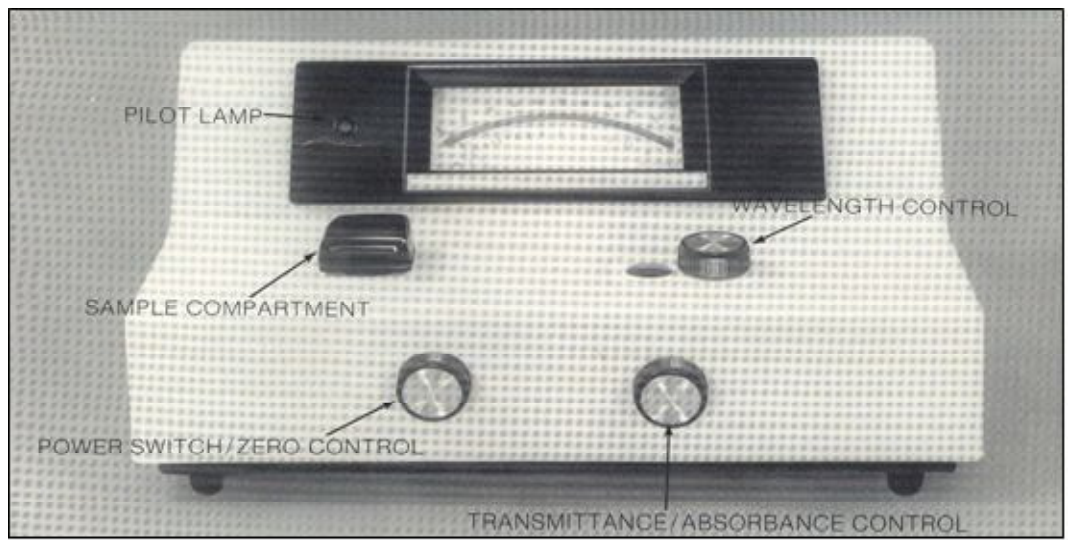

Gambar 1. Alat spektrofotometer, spektronik 20 buatan Bausch dan Lomb

\section{KESIMPULAN}

1. Suatu daerah yang banyak ditumbuhi gulma kadar amonia tinggi, disebabkan terjadi pembusukkan dan sangat tidak baik bagi pertumbuhan dan kehidupan ikan serta organisme lain.

2. Adapun daerah yang bebas dari tumbuhan gulma, maka kadar amonia rendah, dikarenakan tidak ada terjadi pembusukkan dan ini sangat baik untuk pertumbuhan dan kehidupan ikan serta organisme.

\section{DAFTAR PUSTAKA}

Alaerts G. \& Santika. 1984. Metode penelitian air usaha nasional. Surabaya. 309 hal.

Boyd, C. E. 1990. Water quality in ponds for aquaculture. Birmingham Publishing $\mathrm{CO}$. Birmingham Alabama. 482 hal.

APHA. 1985. Standard methods for examination of water and waste water.

Tucker \& Boyd. 1985. Standarr methods for examination of water and waste water. 